\title{
不飽和帯における鉛直浸透時の 移流分散現象に関する研究 STUDY ON ADVECTION DISPERSION PHENOMENA IN THE UNSATURATED VERTICAL INFILTRATION FIELD
}

\author{
齋藤 雅彦 1 ・山北 和之2・中川 啓3 \\ Masahiko SAITO, Kazuyuki YAMAKITA and Kei NAKAGAWA \\ 1正会員 博(工) 神戸大学助教 大学院工学研究科市民工学専攻（广657-8501神戸市灘区六甲台町1-1） \\ 2神戸大学工学部市民工学科（干657-8501神戸市灘区六甲台町1-1） \\ 3正会員 博(工) 長崎大学教授 大学院水産・環境科学総合研究科（一852-8521 長崎市文教町1-14）
}

\begin{abstract}
Macroscopic dispersivity is the most important factor to analyze advection-dispersion equation at the field scale. Any appropriate method for determining this parameter has not been established yet. If the pollutants exist on the ground surface, the behavior of solute is handled as an advection-dispersion phenomenon in the unsaturated vertical infiltration field. And it is known that fingering flow may occur in unsaturated sandy soil. In this study, conventional saturated-unsaturated seepage analysis coupled with $1 / f^{-\zeta}$ model as the geostatistical model of hydraulic conductivity is carried out, and also the advectiondispersion analysis at such an unsaturated infiltration field is carried out. The property of macroscopic dispersivity which is obtained from numerical analysis is investigated.
\end{abstract}

Key Words : groundwater, fingering flow, hydraulic conductivity, macroscopic dispersivity water retention curve

\section{1. 序論}

近年深刻化している地下水污染問題は, 污染された地 表水や下水管からの漏水，下水溜からの污染水の浸透， あるいは，化学肥料や農薬のような污染物質が降雨によ り土塞表面から浸透することによって発生する。また, 2011年3月に発生した東日本大震災の津波による塩害や, がれき・污泥の拡散も広範囲に及び，新たな地下水污染 の懸念が高まっている.

このような地下水污染問題に対して，効率的な污染拡 散防止対策や修復対策を立案するためには，污染物質の 挙動を適切に予測・推定する手法が必要であり，一般的 に水溶性污染物質による土壌・地下水污染問題には，移 流分散解析が用いられる. ここで，分散現象については， 間隙内の流路の不規則性に起因する微視的分散と, 地盤 の不均質性による流速ベクトルの不規則性に起因する巨 視的分散に区別され, 解析の際に重要なパラメータとな る分散長も両者で大きく異なる．とくにフィールドス ケールにおける分散現象を取り扱う際に必要となる巨視 的分散長は，観測スケールに依存性を持つことが明らか
にされており1)，これまでにいくつかの推定法が提案さ れているが2,3)，それらの多くは飽和浸透場を対象とした ものである. 一方, 土壤・地下水污染問題において, 地 表面が污染源となる場合も多く, 污染物質が地表面から 地下水面に至るまでの鉛直浸透過程については，室内実 験スケールでの検討例は見られるものの4)，なお不明な 点が多い. とくに，不飽和帯における鉛直浸透時には， 比較的地盤物性值のばらつきが小さい場合でも条件次第 ではフィンガー流が発生することが知られているが，こ のような場における污染物質の挙動については未解明な 点が多く，定量的な評価方法は確立されていない．これ に対して齋藤(は，飽和・不飽和浸透流解析と，地盤物 性值の空間分布モデル6をを組み合わせることによって, 鉛直浸透時に生じるフィンガリング現象を有限要素法に よって簡易に再現可能であることを示すとともに，不飽 和浸透特性との関連について検討している.

本研究では不飽和・不均一鉛直浸透場における移流分 散現象について，地盤物性值の空間分布モデルを用いた 数值シミュレーションにより, 不飽和浸透特性および浸 透強度の影響等について定量的な考察を試みる。 


\section{2．基礎方程式と地盤物性値}

\section{（1） 飽和 $\cdot$ 不飽和浸透流解析}

飽和・不飽和浸透流の基礎式7-9) は以下のように表さ れる.

$$
\left(\phi \frac{d S_{w}}{d \psi}+\beta S_{s}\right) \frac{\partial \psi}{\partial t}=\nabla \cdot[\mathbf{K} \cdot(\nabla \psi+\nabla Z)]
$$

ここに， $\phi$ は空隙率， $S_{w}$ は飽和度， $S_{S}$ は比貯留率， $\mathbf{K}$ は透水係数テンソル, $\psi$ は圧力水頭, $Z$ は位置水頭で ある. また, $\beta$ は, 飽和領域 $\left(S_{\mathrm{w}}=1\right)$ で $\beta=1$, 不飽和領 域 $\left(S_{\mathrm{w}} \neq 1\right)$ で $\beta=0$ である. また, 透水係数テンソルは, 比透水係数 $k_{r}$ および飽和透水係数テンソル Ks により 以下のように表すことができる.

$$
\mathbf{K}=k_{r} \cdot \mathbf{K s}
$$

境界条件は, 圧力水頭 $\psi$ が既知の境界 $\Gamma_{1}$ 上で,

$$
\psi=\psi_{1} \quad \text { on } \quad \Gamma_{1}
$$

流束 $q$ が既知の境界 $\Gamma_{2}$ 上で,

$$
q=q_{2}=-\mathbf{n} \cdot \mathbf{K} \cdot(\nabla \psi+\nabla Z) \text { on } \Gamma_{2}
$$

ここに， $\psi_{1}$ および $q_{2}$ はそれぞれ既知の圧力水頭と流束， nは境界面上の単位外向法線ベクトルである.

\section{（2）不飽和浸透特性}

解析に必要な水分特性曲線は, 式(5)のvan Genuchten の式10)を用いる.

$$
S_{e}=\frac{S_{w}-S_{r}}{1-S_{r}}=\left\{1+\left(\alpha \psi_{c}\right)^{n}\right\}^{-m}
$$

ここに， $\psi_{c}$ は毛管圧 $(=-\psi) ， S_{e}$ は有効飽和度， $S_{r}$ は 残留飽和度, $\alpha, n, m$ は形状パラメータであり $, n, m$ は無 次元, $\alpha$ は圧力水頭の逆数の次元を持つ. また, $n$ と $m$ の関倸は, $m=1-1 / n$ とする.

また，比透水係数と有効飽和度の関係は，

$$
k_{r}=S_{e}{ }^{\varepsilon}\left\{1-\left(1-S_{e}^{1 / m}\right)^{m}\right\}^{2}
$$

と表される11)。ここに， $\varepsilon$ は空隙の連続性に関わるパラ メータであり， $\varepsilon=1 / 2$ とする.

\section{（3）移流分散方程式}

地下水流による水溶性物質の輸送過程の基礎式（移流 分散方程式）は，以下のように表される。

$$
\theta \frac{\partial c}{\partial t}=\nabla \cdot(\theta \mathbf{D} \cdot \nabla c)-\mathbf{q} \cdot \nabla c
$$

ここで， $c$ は濃度， $\theta$ は体積含水率 $\left(=\phi S_{w}\right), \mathbf{D}$ は分散 係数テンソル， $\mathbf{q}$ はダルシー流速ベクトルである.ま た，式(8)におけるD成分 $D_{i j}$ は，次式で与えられる ${ }^{12}$.

$$
\theta D_{i j}=a_{T}|\mathbf{q}| \delta_{i j}+\left(a_{L}-a_{T}\right) \frac{q_{i} \cdot q_{j}}{|\mathbf{q}|}+\theta D_{m} \delta_{i j}
$$

ここで， $\alpha_{L}$ は流れ方向の分散長， $\alpha_{T}$ は流れに垂直な方 向の分散長, $q_{i}$ はダルシー流速ベクトル $\mathbf{q}$ の $i$ 方向成分, $D_{m}$ は分子拡散係数， $\delta_{i j}$ はクロネッカーデルタテンソル の成分である.

境界条件は，濃度 $c$

$$
c=c_{A} \text { on } \quad \Gamma_{\mathrm{A}}
$$

濃度勾配 $F_{\mathrm{B}}$ が既知の境界 $\Gamma_{\mathrm{B}}$ 上で,

$$
F=F_{B}=-\mathbf{n} \cdot(\theta \mathbf{D} \cdot \nabla c) \text { on } \quad \Gamma_{\mathrm{B}}
$$

ここに， $c_{A}$ は既知の濃度， $F_{\mathrm{B}}$ は既知の濃度勾配である 式(9)を通常のガラーキン法により離散化すると, 移 流項が卓越寸る場合に解が不安定になることが知られて いる.この不安定性を抑制するため、本研究では特性曲 線ガラーキン法13)を用いた.

\section{（4）透水係数の空間分布モデル}

本研究では，透水係数分布を決定するのに，パワースペクト 儿密度関数が $f$ 型となるモデルを使用した。これは透水係数 の刘数変換值 $\left(Y=\log _{10}(k)\right)$ のパワースペクトル密度関数が次式の ように $f$ 型となるものであり，実地盤における透水係数の空 間分布特性を容易に模疑し得ることを確忍している6).

$$
S(|\boldsymbol{f}|) \propto|\boldsymbol{f}|^{-\zeta}
$$

ここに，fは空間周波数ベクトル， $S f f D$ はパワースペクトル， らは空間的な相関性を表わ寸パラメータであり，2 次元モデル の場合， $\fallingdotseq 2$ である. またこのモデルを用いた場合， $\log _{10} k$ の分散 $\sigma_{k}^{2}$ と空間解像度 $N$ の関係は以下の式で表される ${ }^{14)}$

$$
\sigma_{k}^{2}=\lambda \log _{10} N
$$

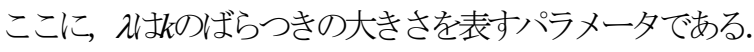

\section{（5）不飽和浸透特性の空間分布}

水分特性曲線としてvan Genuchtenの式を用いる場合, パラメータとして $\alpha, n$, およひ残留飽和度 $S_{r}$ を決定する 必要がある. 本研究では, 砂質土を用いた谷中ら ${ }^{15)}$, お 


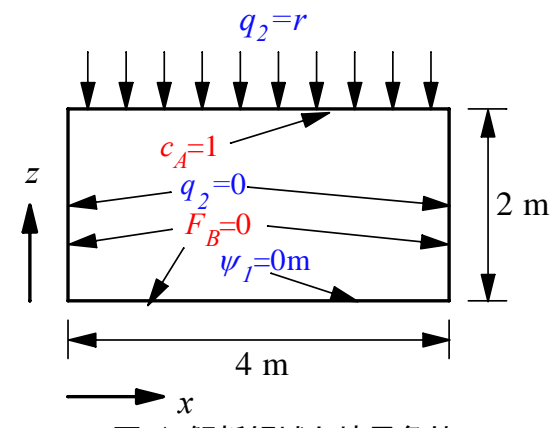

図-1 解析領域と境界条件

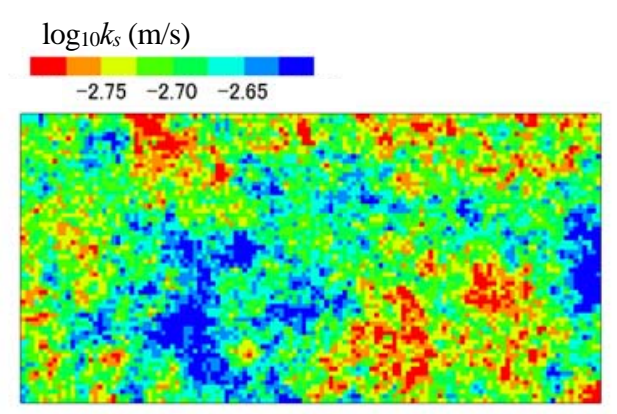

図-2 飽和透水係数分布 $\left(k_{s a}=2.0 \times 10^{-3} \mathrm{~m} / \mathrm{s}\right)$

表-1 解析ケース

\begin{tabular}{|c|c|c|c|}
\hline & $n$ & $k_{s a} \mathrm{~cm} / \mathrm{s}$ & $r \mathrm{~mm} / \mathrm{h}$ \\
\hline Case0 & 8 & 0.2 & \multirow{2}{*}{5} \\
\cline { 1 - 2 } Case1-1 $\sim 6$ & $2,3,4,5,6,7$ & 0.2 & \\
\cline { 1 - 2 } Case2-1 $\sim 6$ & \multirow{2}{*}{8} & $0.02,0.03,0.04,0.05,0.1,0.15$ & \\
\cline { 1 - 2 } Case3-1 7 & & 0.2 & $10,15,20,25,30,35,100$ \\
\hline
\end{tabular}

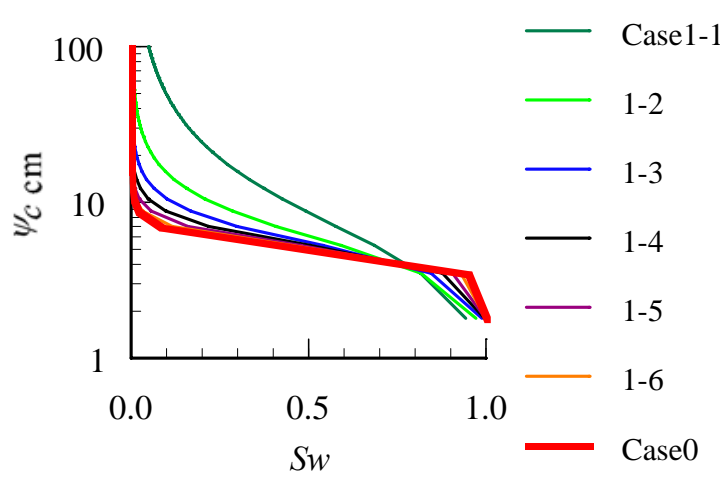

図-3 水分特性曲線（Case0, Case1-1～6）
よびガラスビーズを用いた中川ら 16)よって報告されて いる室内試験結果に基づき，飽和透水係数 $k_{\mathrm{s}}$ と主脱水 曲線の $\alpha\left(=\alpha_{d}\right) の$ 関係を式(13)のように決定した ${ }^{17)}$.

$$
\alpha_{d}{ }^{-1}=-37.35 \log _{10} k_{s}-16.22
$$

ここに， $\alpha_{d}$ の単位は $\mathrm{cm}^{-1}, k_{s}$ の単位は $\mathrm{cm} / \mathrm{s}$ あ゙あり, $\alpha_{d}^{-1} \geq 1.0(\mathrm{~cm})$ とする. 主吸水曲線の $\alpha\left(=\alpha_{w}\right)$ は, Luckner et al. ${ }^{18)}$ を参考に $\alpha_{w}=2 \alpha_{d}$ とする. また, 残留飽 和度 $S_{r}$ については，一般的に $k_{s}$ が大きいほど $S_{r}$ は小 さくなる傾向があることから，いくつかの実測例を参考 に $k_{s}$ の関数として，便宜的に式(14)のように仮定する.

$$
S_{r}=-0.15 \log _{10} k_{s}-0.2
$$

ここに, $S_{r}$ は無次元， $k_{s}$ の単位は $\mathrm{cm} / \mathrm{s}$ であり, $S_{r} \geq 0.0$ とする. パラメータ $n$ については， $k_{s}$ との明瞭な相関 関係を確認できなかったので，空間的に一定值とする.

\section{3. 解析条件}

（1）解析領域および境界条件

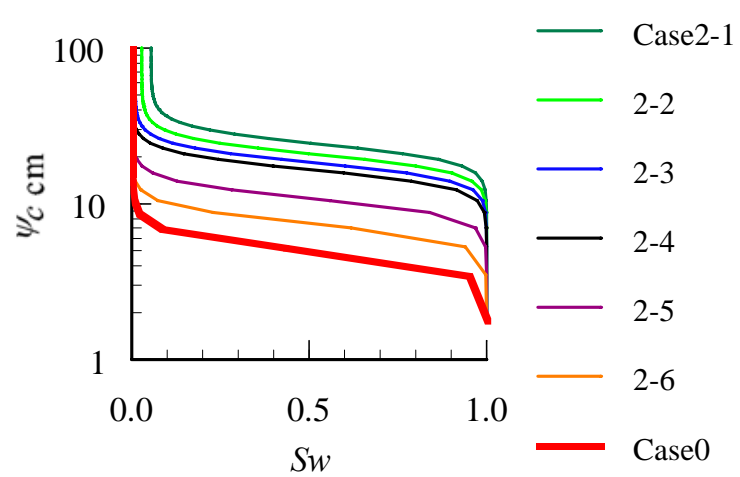

図-4 水分特性曲線（Case0, Case2-1～6）

図-1に，設定した解析領域と境界条件を示す。解析領 域は，幅 $4 \mathrm{~m}$ ・高さ $2 \mathrm{~m}$ の断面2次元領域とし，上端面は地 表面，下端面は地下水面である. 浸透流解析における境 界条件は，上端面は浸透量一定 $(q=r)$ ，下端面は大気 圧（ $\psi=0 ）$ ，両側面は不透水性境界 $(q=0)$ とする。移 流分散解析における境界条件は，上端面で濃度一定

$(c=1)$ ， その他の境界では濃度勾配一定 $\left(F_{B}=0\right)$ とす る. 解析メッシュは, すべて正方形要素で構成し, 要素 数は $N=8192 （ 128 \times 64 ）$ ，要素サイズは3.125cm × $3.125 \mathrm{~cm}$ とする.

\section{（2）地盤物性值}

飽和透水係数分布は, 前述した透水係数の空間分布モ デルを用いて生成する，ここで，要素ごとに与える飽和 透水係数は等方性とし，その幾何平均值 $k_{s a}$ およびばらつ きの大きさを表す式(12)のパラメータれによってその統 計的性質が決定される.ここでは，均一場に近い性質を 与えるため $\lambda=6.0 \times 10^{-4}$ とているが，このときの $\sigma_{k}$ は式 (12)より $\sigma_{k}=0.048$ となる. 図 -2 に飽和透水係数の幾何平 均值を $k_{s a}=0.2 \mathrm{~cm} / \mathrm{s}$ とした場合の飽和透水係数分布を示す. 式(8)に用いられる分散長は，微視的分散のみを考え， 縦分散長は要素サイズの0.1倍 $\left(\alpha_{L}=3.125 \times 10^{-3} \mathrm{~m}\right)$ とし， 横分散長は $\alpha_{T}=3.125 \times 10^{-4} \mathrm{~m}$, 分子拡散係数は $D_{\mathrm{m}}=1.0 \times$ 


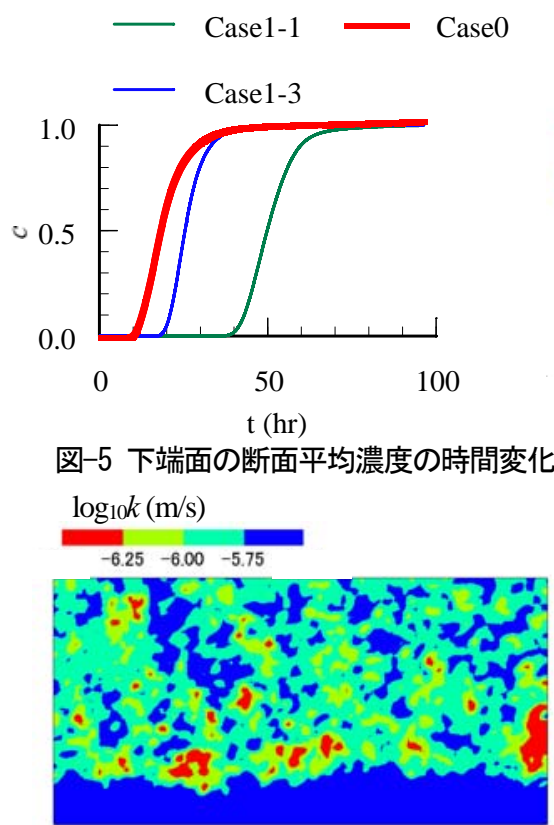

(a) Case1-1

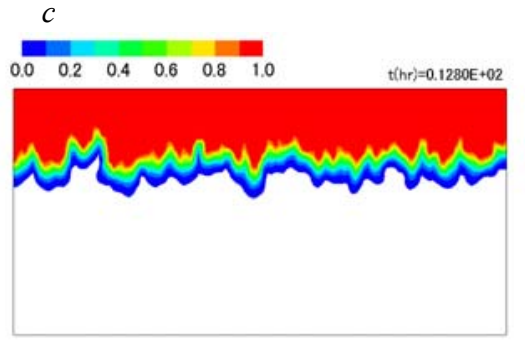

図-6 濃度分布（Case1-1， t=12. 8hr）

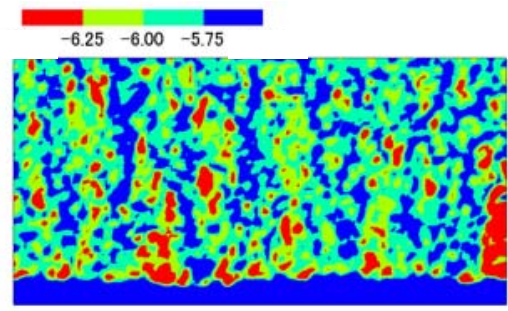

(b) Case1-3

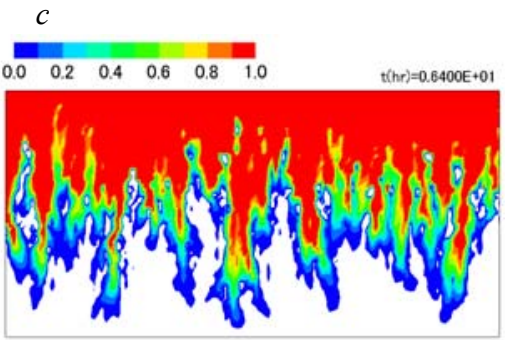

図-7 濃度分布（Case0，t=6.4hr）

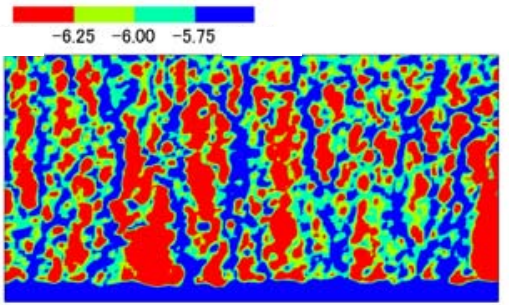

(c) Case0

図-8＼cjkstart不飽和透水係数分布

$10^{-9} \mathrm{~m}^{2} / \mathrm{s}$ とする. その他，式(1)における空隙率は $\phi=0.4$, 比貯留率は $S_{S}=0$ とする.

\section{（3）解析手順と解析ケース}

図-1に示した解析領域において，まず単独で浸透流解 析を実施し，定常状態における流速分布を求める. この とき，初期条件として全領域で $S_{w} \fallingdotseq S_{r}$ となるように一定 の初期水圧分布 $(\psi=-10 \mathrm{~cm} \sim-100 \mathrm{~cm})$ を与える. このため, 領域内の水分は乾燥から湿潤の方向一変化するので, 水 分特性曲線は主吸水曲線を用いる。つぎに，得られた流 速分布を用いて移流分散解析を行う。この結果，濃度分 布の時間変化が得られるが，ここで下端面における断面 平均濃度の時間変化を求め, これを以下の1次元移流分 散方程式の理論解で近似寸ることによって，見かけの間 隙流速と巨視的分散長を同定する.

$$
\frac{c}{c_{0}}=\frac{1}{2} \operatorname{erfc}\left(\frac{z-v^{\prime} t}{2 \sqrt{D^{\prime} t}}\right)+\frac{1}{2} \exp \left(\frac{v^{\prime} z}{D^{\prime}}\right) \operatorname{erfc}\left(\frac{z+v^{\prime} t}{2 \sqrt{D^{\prime} t}}\right)
$$

ここに, $D^{\prime}$ は巨視的分散係数 $\left(=a_{L}^{\prime} v^{\prime}\right) 、 \alpha_{L}^{\prime}$ は巨視的 分散長, $v^{\prime}$ はz方向の見かけの間隙流速である. 解析 ケースは，まずフィンガー流の最も発生しやすい条件

（透水性が大きく，かつ保水性が小さい）7)をCase0とし， 水分特性曲線のパラメータ $n$, 飽和透水係数の平均值 $k_{s a}$, および浸透量 $r$ をれぞれ単独で変化させた．各ケース において用いたパラメータを表-1に示す。また， $n$ と $k_{s a}$ を変化させた際の水分特性曲線を図-3および図-4に示す． ただし，水分特性曲線は式(13)および式(14)により，各 要素の飽和透水係数 $k_{s}$ に応じて空間的に変化させている ため, 各図に示した水分特性曲線は平均的なものである.

\section{4. 解析結果と考察}

(1) Case1-1 6

図-5は，Case0，Case1-1およびCase1-3における下端面 の断面平均濃度の時間変化を示している. これらは, 水 分特性曲線のパラメータ $n$ のみが異なるが, $n$ が大きくな るほど下端面に早く到達寸ることがわかる．また，図-6 および図-7は，それぞれCase1-1とCase0の濃度分布（た だし c $>0.01)$ であるが，Case1-1ではt=12.8hrで全体的に 1/3程度の深度までしか到達していないのに対し, Case0 ではt=6.4hrで局所的にはほぼ下端面付近まで到達してい る部分がある，さらに，図-8はそれぞれの不飽和透水係 数 $k$ の分布を比較したものである. 地下水面以上の不飽 和帯においては, 鉛直浸透量 $r$ 応じて不飽和透水係数 が決まるため, ここでは $r=5 \mathrm{~mm} / \mathrm{h}\left(=1.39 \times 10^{-6} \mathrm{~m} / \mathrm{s}\right)$ が 基準となる. このため, 図-2の飽和透水係数と比較して 全体的に3オーダー以上小さくなっているが，nが大きく なるほど水みちとなる局所的に高透水性の部分が生じ, フィンガー流がより顕著に現れることがわかる。 これら の違いを定量的に評価するため, 断面平均濃度の時間変 化から，それぞれのケースについて巨視的分散長と見か けの間隙流速を同定したものが図-9および図-10である. ここで，図-10では，同定された見かけの間隙流速快は, 飽和状態における間隙流速 $r^{\prime}(=r / \phi)$ に対する比で表してい る. 図-9より, 巨視的分散長は $n$ に忍じてほぼ指数関数 的に増加し, $n=2$ では $0.02 \mathrm{~m}$ （流下距離の $1 / 100 ）$ 程度, $n=8$ では $0.1 \mathrm{~m}$ 程度に増加することがわかる。.つまり，巨 視的分散長はフィンガー流の発生により概ね 25 倍程度大 きくなることがわかる，また，図-10より見かけの間隙 


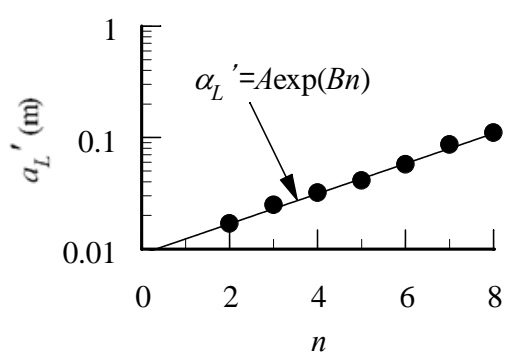

図-9 巨視的分散長の同定結果

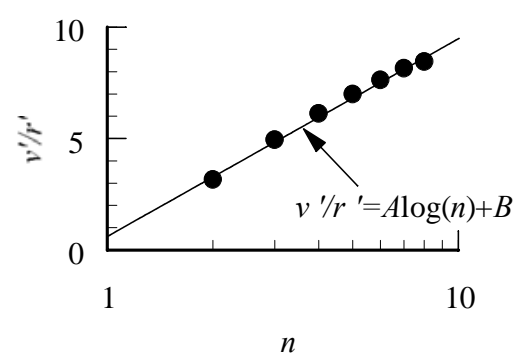

図-10 見かけの間隙流速の同定結果

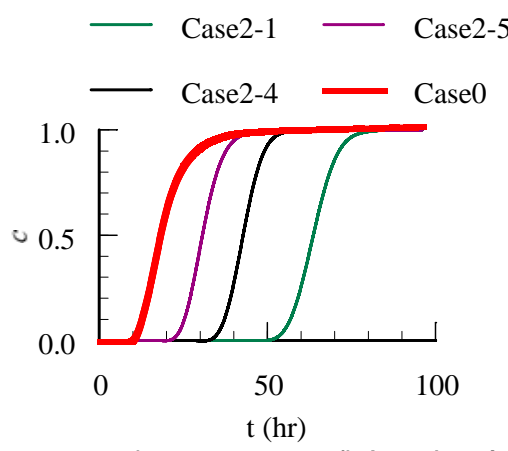

図-11 下端面の断面平均濃度の時間変化

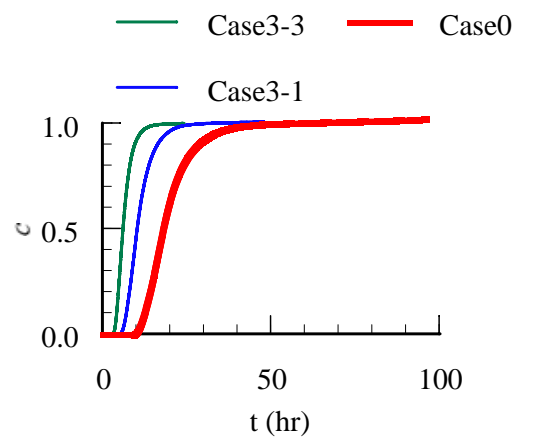

図-14 下端面の断面平均濃度の時間変化

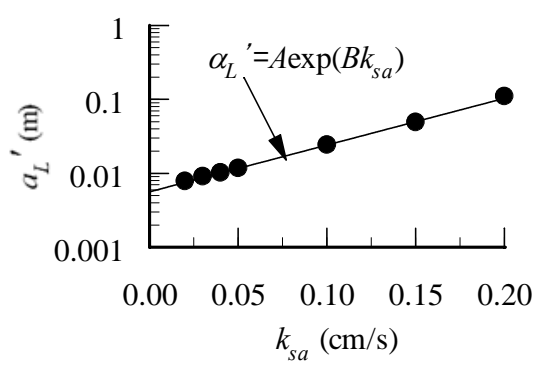

図-12 巨視的分散長の同定結果

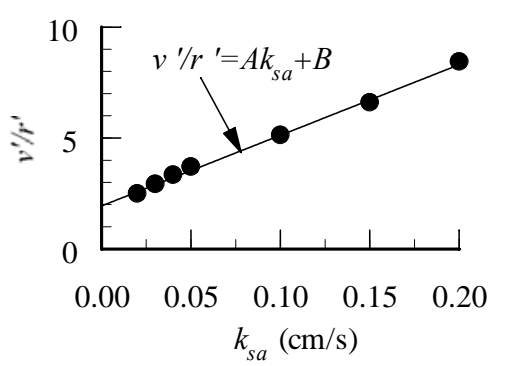

図-13 見かけの間隙流速の同定結果

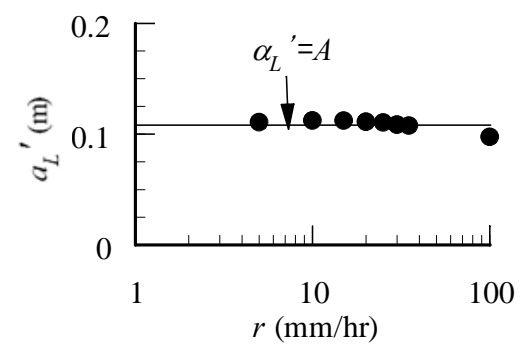

図-15 巨視的分散長の同定結果

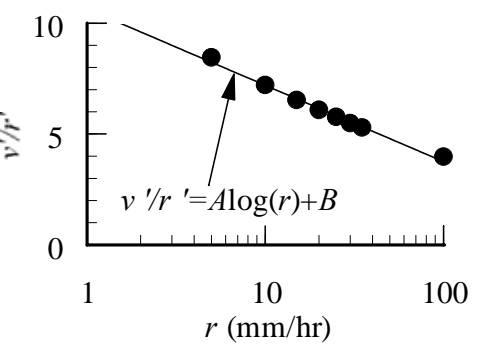

図-16 見かけの間隙流速の同定結果
流速は, $n$ に対して対数関数的に増加し, フィンガー流

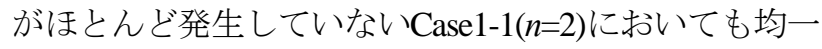
場の間隙流速に対して約3倍, Case0 $(n=8)$ では, 約8倍 に増加していることがわかる. これは, 保水性が小さく なると全体的に体積含水率 $\theta か ゙$ 低下寸るため, ダルシー 流速を $q$ とすると，間隙流速 $q / \theta$

\section{(2) Case2-1 6}

図-11は，Case0，Case2-1，Case2-4およびCase2-5にお ける下端面の断面平均濃度の時間変化を示している. こ れらは，飽和透水係数の平均值 $k_{s a}$ のみが異なるが，これ により水分特性曲線のパラメータ $\alpha$ に違いを与えている

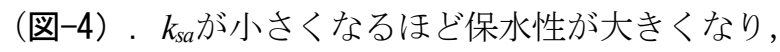
フィンガー流は発生し難くなるため下端面に到達するま での時間は長くなる. 図-12および図-13は, 巨視的分散 長と見かけの間隙流速を同定したものである.これより， 巨視的分散長は飽和透水係数に応じてほぼ指数関数的に 増加し, $k_{s a}=0.02 \mathrm{~cm} / \mathrm{s} \sim 0.05 \mathrm{~cm} / \mathrm{s}$ では $\alpha_{L}{ }^{\prime}$ は $0.01 \mathrm{~m}$ 程度と Case0の約1/10となっている. また，見かけの間隙流速 $\mathrm{v}$ ' は, 飽和透水係数に応じて概衩線形的に変化している.
(3) Case3-1 7

図-14は，Case0，Case3-1およびCase3-3における下端 面の断面平均濃度の時間変化を示している. 上端面から の浸透流量 $r$ を増加させると, それに応じて間隙流速も 大きくなるため, 下端面の濃度はより早く上昇する。 ま た，図-15は巨視的分散長の同定結果であるが，これは 浸透量に依存せず, 約0.1mで一定となっている. 一方, 図-16は，見かけの間隙流速の同定結果であるが， v'の $r^{\prime}$ に対する比は浸透量の対数值に対して線形的に減少して いる. 図-17は，それぞれCase3-1 $(r=10 \mathrm{~mm} / \mathrm{hr})$ とCase3$7(r=100 \mathrm{~mm} / \mathrm{hr})$ の場合において下端面の断面平均濃度が 上昇し始める直前の濃度分布を示しているが，両者の分 布形状に顕著な相違は見られない。 これより, 飽和透水 係数より十分小さい浸透量（例えば $r=100 \mathrm{~mm} / \mathrm{h}$ の場合,

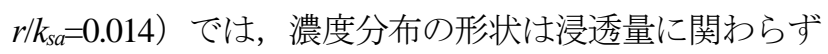
概ね同様となるため, 巨視的分散長も一定となる. 一方, このときの時刻はCase3-1 では $t=4.27 \mathrm{hr}$, Case3-7では $t=0.93 \mathrm{hr}$ とっており, 浸透量は10倍になっても下端面 に到達するまでの時間は $1 / 5$ 程度となっている。これは, 浸透量の増加に伴う体積含水率の上昇のため, 相対的に 間隙流速が低下寸ることが主因と考えられる. 


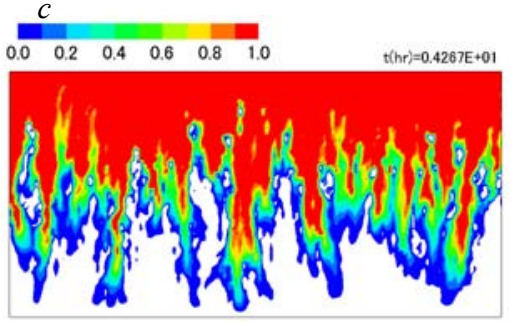

(a) Case $-1, \quad t=4.27 \mathrm{hr}$

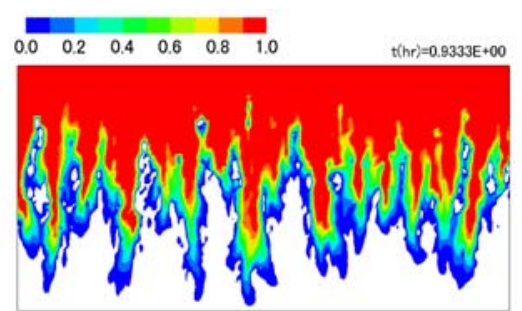

(b) Case3-7, $\mathrm{t}=0.93 \mathrm{hr}$

図-17 濃度分布

\section{8. 結論}

本研究では，不飽和・不均一鉛直浸透場における移流 分散現象について，地盤物性值の空間分布モデルを用い た数值シミュレーションにより，不飽和浸透特性および 浸透強度の影響等について定量的な考察を試みた。 以下 に得られた結論を示す。

1) 水分特性曲線のパラメータnがフィンガー流の発生 に大きく関わり，巨視的分散長は $n$ に対して指数関 数的に増加する.

2）飽和透水係数と水分特性曲線のパラメータ $\alpha$ に強い 相関を仮定すると，高透水性 $\left(k_{s a}>0.1 \mathrm{~cm} / \mathrm{s}\right)$ の場合 にフィンガー流が発生しや寸く，体積含水率の低下 により見かけの間隙流速は飽和時の5倍以上となる 可能性がある.

3) 鉛直浸透量が飽和透水係数よりも十分小さい場合, 濃度分布の形状はほとんど変化しない。

なお，これらの結果は前提条件としていくつかの仮定 に基づいた上での定量的な検討であり，全体的な傾向は 妥当なものと考えるが，今後はここでは考慮していない 要因（例えば対象領域の大きさ，不均一性の強さ等）に ついての検討，また模型実験や実地盤における実測例を 充実させていく必要があると考える.

謝辞 : 本研究はJSPS科研費（25420504）の助成を受けたもので ある.ここに記して謝意を表す。

\section{参考文献}

1) Gelhar, L.W., C. Welty and K.R.Rehfeldt: A Critical review of data on field-scale dispersion in aquifers, Water Resources Research, Vol.28, No.7, pp.1955 1974, 1992.

2) Neuman, S. P. : Universal scaling of hydraulic conductivities and dispersivities in geologic media. Water Resources Research, 26, pp.1749 1758, 1990.

3) 齋藤雅彦, 西村由紀子, 中川 啓: 自己相似型不均一地盤 モデルを用いた巨視的分散長の定量的評価に関する研究， 地下水学会誌, Vol.53, No.4, pp.343-355, 2011.

4) 齊藤雅彦，中川 啓 : 不飽和不均一鉛直浸透場の物質移動 現象に関する室内実験と数値シミュレーション, 土木学会 論文集，Vol.66, No.3, pp.248-257, 2010.
5) 齋藤雅彦 : 飽和・不飽和浸透流解析による不均一地盤内の フィンガリング現象に関する研究，水工学論文集，第 50 巻, pp217-222, 2006.

6) 齋藤雅彦，川谷 健 : 透水係数の空間分布モデルの適用性 に関する一考察, 土木学会論文集, No.694, III-57, pp.245258, 2001.

7) Neuman, S. P.: Saturated unsaturated seepage by finite elements, Proc., ASCE HY, Vol.99, No.12, pp.2233-2250, 1973.

8) Neuman, S. P.: Galerkin method of analyzing non-steady flow in saturated-unsaturated porous media, Finite element Method in flow problem, edited by C. Taylor, O.C. Zienkiewicz, R.H. Gallagher, John Wiley \& Sons, Chap.19, 1974.

9) 赤井浩一, 大西有三，西垣 誠 : 有限要素法による飽和-不 飽和浸透流の解析, 土木学会論文集, 第 264 号, pp.87-96, 1977.

10) van Genuchten, M. T.: A closed-form equation for predicting the hydraulic conductivity of unsaturated soils, Soil Science Society America Journal, Vol.44, pp.892-898, 1980.

11) Mualem, Y. : A new model for predicting the hydraulic conductivity of unsaturated porous media, Water Resources Research, Vol.12, pp.513-522, 1976.

12) Bear, J. : Dynamics of Fluid in Porous Media, Elsevier, New York, 1972.

13) Zienkiewicz, O. C. and Taylor, R. L.: The Finite Element Method, Vol.3, (5th ed.), Butterworth-Heinemann, pp.13-63, 2000.

14) 齋藤雅彦, 西村由紀子, 中川 啓 : 自己相似型不均一地盤 モデルを用いた巨視的分散長の定量的評価に関する研究, 地下水学会誌，第 53 巻，第 4 号, pp.343-355, 2011.

15) 谷中仁志, 石田哲朗 : 砂質土における比透水係数曲線 $(\theta-\mathrm{kr})$ の検討, 第 33 回地盤工学研究発表会, pp.1817-1818, 1998.

16) 中川 啓, 岩田将英, 筑紫二郎, 粐井和朗 : 不飽和-不均一 多孔媒体における物質輸送特性について : 水工学論文集, 第 47 巻, pp.337-342, 2003.

17) 齋藤雅彦, 川谷 健 : 地盤の不均質を考慮した降雨浸透・ 浸出過程の気液 2 相流数值シミュレーション, 水工学論文 集, 第 48 巻, pp.319-324, 2004.

18) Luckner, L., van Genuchtn, M.Th. and Nielsen, D.R.: A Consistent Set of Parametric Models for the Subsurface, Water Resources Research, Vol.25, pp.2187-2193, 1989. 